\title{
Entrepreneurial and Market Orientation in Beekeeping Enterprises
}

\author{
Anca A. POPOVICI ${ }^{1) *}$, Liviu Al. MĂRGHITAŞ ${ }^{1}$, Daniel S. DEZMIREAN ${ }^{1)}$, Marioara ILEA $^{2)}$ \\ ${ }^{1)}$ Department of Apiculture and Sericulture, Faculty of Animal Science and Biotechnologies, University \\ of Agricultural Sciences and Veterinary Medicine, 3-5 Calea Mănăştur, 400372, Cluj-Napoca, Romania; \\ ${ }^{2)}$ Department of Economic Sciences, Faculty of Horticulture, University of Agricultural Sciences and \\ Veterinary Medicine, 3-5 Calea Mănăştur, 400372, Cluj-Napoca, Romania; \\ *Corresponding author, e-mail: anca.popovici@usamvcluj.ro
}

Bulletin UASVM Animal Science and Biotechnologies 72(2) / 2015

Print ISSN 1843-5262; Electronic ISSN 1843-536X

DOI:10.15835/buasvmcn-asb:11402

\begin{abstract}
It has been largely demonstrated that entrepreneurial and market orientations contribute to business performance. In this context, the main objective of the present study is to investigate the influence of entrepreneurial and market orientations upon the profitability of beekeeping enterprises. Based on a survey conducted on 100 beekeeping enterprises in France and 160 in Romania, linear regression was run to assess the relationship between several factors and beekeeping enterprises' profitability. The findings show a similarity between the two countries, as innovativeness, proactiveness, market orientation, the number of honeybee colonies, the diversification of the products sold and of the distribution channels are the main factors influencing the profitability of beekeeping enterprises in both countries. The risk-taking dimension impacts on profitability only in France. The paper provides insights into the strategies that enhance the competitive advantage of beekeeping enterprises.
\end{abstract}

Keywords: innovativeness, proactiveness, risk-taking, customer orientation, profitability

\section{INTRODUCTION}

Literature shows that entrepreneurial orientation (EO) and market orientation (MO) influence firm profitability and performance (Baker and Sinkula, 2009; Lumpkin and Dess, 1996; Narver and Slater, 1990; Rauch et al., 2009; Slater and Narver, 1998; Wiklund, 1999; Wiklund and Shepherd, 2005). The entrepreneurial orientation construct was first conceptualized by Miller (1983), who stated that an entrepreneurial firm is one that "engages in product-market innovation, undertakes somewhat risky ventures, and is first to come up with proactive innovations, beating competitors to the punch". The concept of entrepreneurial orientation was afterwards developed by Covin and Slevin (1989), who ranked firms as entrepreneurial if they were innovative, risk-taking and proactive. Most researchers agree that the entrepreneurial orientation is a combination of three dimensions: innovativeness, proactiveness and risk-taking (Rauch et al., 2009). Research suggests that each of the three dimensions can have a universal positive effect on performance (Wiklund and Shepherd, 2005).

Innovativeness is the predisposition to engage in creativity and experimentation through the introduction of new products/services, as well as technological leadership via R\&D in new processes (Rauch et al., 2009). Innovation in entrepreneurial firms is considered an important factor in facilitating growth, offering new products with high profit potential (Wiklund et al., 2009). Innovative firms introduce new products and services that are more attuned to current and emerging market needs, being able to quickly enter into new markets (Morris et al., 2011). According to Ireland and Hitt (1999), opportunities are addressed most effectively through innovation and creativity. 
Proactiveness, the second dimension, refers to processes which aim at "seeking new opportunities, introduction of new products and brands ahead of competition and strategically eliminating operations which are in the mature or declining stages of the life cycle" (Venkatraman, 1989). Proactiveness is an opportunity-seeking, forward-looking perspective characterized by the introduction of new products and services ahead of the competition and acting in anticipation of future demand (Rauch et al., 2009).

Risk-taking is often used to describe the uncertainty that results from entrepreneurial behaviour (Lumpkin and Dess, 1996). Risk taking involves taking bold actions by venturing into the unknown, borrowing heavily, and/or committing significant resources to ventures in uncertain environments (Rauch et al., 2009). High levels of risk-taking are sometimes associated with a higher likelihood of failure (Alvarez, 2007), while moderate levels of risk-taking may be most beneficial to SME performance (Miller and Leiblein, 1996; Morris et al., 2011), instead of extreme and uncontrolled risky endeavours.

Lumpkin and Dess (1996) and Kreiser et al. (2002) show that the three dimensions can vary independently from each other and should be allowed to vary, as not all of the dimensions of entrepreneurial orientation affect business performance directly or positively under different circumstances. Hughes and Morgan (2007) found that the entrepreneurial orientation dimensions of proactiveness and innovativeness were positively related to firm performance, while risk-taking was not. According to Kreiser et al. (2013), there is a predominantly positive relationship between innovativeness-performance and proactivenessperformance and a predominantly negative relationship between risk-taking and performance.

Market orientation reflects the extent to which firms establish the satisfaction of customer needs and wants as an organizing principle of the firm (Jaworski and Kohli, 1993). The concept of market orientation implies both responsive market orientation, which addresses the expressed needs of customers, and proactive market orientation, which addresses the latent needs of customers (Narver et al., 2004). According to the literature, market orientation influences firm profitability (Baker and Sinkula, 2009; Hult and Ketchen, 2001; Slater and Narver, 1998).
Atuahene-Gima and Ko (2001) argue that an alignment of market and entrepreneurial orientation processes and practices enables the firm to manage its market environment to meet current and emerging customer needs. Baker and Sinkula (2009) found that entrepreneurial orientation and market orientation complement one another in order to enhance profitability.

Theliterature addressing the apicultural sector emphasises the fact that certain factors influence the profitability of beekeeping enterprises: the transition from traditional apiculture to modern apiculture, the adoption of innovations in the apicultural business (Ja'afar-Furo et al., 2007); the apiarists' farming experience, the number of honeybee colonies (Bodescu et al., 2009; Kalule and Ssebbale, 2014; Masuku, 2013; Singh and Sekhon, 2014); the replacement of human labour by mechanical labour (Makri et al., 2012); product diversification (Marinković and Nedić, 2010); increased honey production (Popescu, 2012); practicing mixed beekeeping (both stationary and migratory) (Pocol and Popa, 2012). The influence of the entrepreneurial and market orientations upon the profitability of beekeeping enterprises has not been studied until now.

The purpose of the present paper is to identify the factors that influence the profitability of French and Romanian beekeeping enterprises. Therefore, the following aspects are evaluated: the entrepreneurial orientation (with its three dimensions: innovativeness, proactiveness, risktaking), the market orientation, the number of honeybee colonies, the diversification of products sold and distribution channels.

The reason for analysing the business strategies of entrepreneurial and market orientation is that beekeeping enterprise owners should develop new business strategies in order to be competitive. If they compete efficiently, their strategic decisions have the potential to influence firm profitability.

\section{MATERIALS AND METHODS}

Data were collected by means of an email survey from July until October 2014. A structured questionnaire was sent to the owners of 1,300 beekeeping enterprises each in France and in Romania. We chose these two European countries because they are among the leading producers of honey in Europe (Chauzat et al., 2013). In 
France, out of the 1,300 beekeeping enterprises ${ }^{1}$, 107 responded and filled in the questionnaires, which is a response rate of $8.23 \%$. Within the 107 respondents, 7 entrees were dropped because they were not complete. In Romania, out of the 1,300 beekeeping enterprises ${ }^{2}$, a total of 165 valid responses were received, which is a response rate of $12.6 \%$. Within the 165 respondents, 5 entrees were dropped because they were not complete. This resulted in 100 valid responses from France and 160 from Romania to be used in the statistical analysis. The data were analysed using SPSS statistical program v. 19.

The questionnaire covered personal data of the owner-manager, such as gender, age, education, beekeeping experience. It also included questions related to entrepreneurial orientation, market orientation, apiary size (number of honeybee colonies), the legal status of the firm, the type of beekeeping practiced, the age of the beekeeping enterprise, the number and type of products sold, the diversification of the distribution channels, the export of bee products.

Profitability was measured with a three-item scale consisting of the following questions: "Is the enterprise profitable or does it operate at a loss?", "Has the enterprise profit increased over the last 3 years?", "Has the enterprise turnover increased over the last 3 years?".

The three dimensions of entrepreneurial orientation were assessed using seven items adapted from the original Covin and Slevin (1989) measure. All seven items were measured using a five-point Likert-type scale. Three items were used to measure innovativeness: "The enterprise has company-specific innovative products that it currently sells", "The enterprise invests in the development of new products", "The enterprise has marketed new product lines during the past 5 years". Three items were used to measure proactiveness: "In dealing with its competitors, the enterprise is very often the first to introduce new

1 The email addresses of apicultural enterprises in France were found on the websites: https://apiculteurs.info/liste, http://abeille.gudule.org/. Emails were also sent to several associations in France (Union Nationale de l'Apiculture Française, Institut de l'Abeille, Association éleveurs de reines) that sent the email to several of their members.

2 In Romania, the questionnaire was sent through email to several beekeepers' discussion groups (Proapicultura, Apiterapy group etc.) and to diffrent apicultural enterprises across the country. products", "Our main task is to pursue valuable opportunities and then to acquire the suitable resources to exploit them", "We seek new markets for our products". One item was used to measures risk-taking: "Generally, the enterprise favours high risk projects (with chances of very high returns)".

Market orientation was measured using four items of the MORTN scale developed by Deshpande and Farley (1998): "We continually monitor customers to find new ways to improve customer satisfaction", "Our strategy for competitive advantage is based on our understanding of customers' needs", "We poll our customers at least once per year to assess the quality of our products", "Our business objectives are driven primarily by customer satisfaction". The four items were measured using a five-point Likert-type scale.

An exploratory factor analysis was performed to test the multidimensionality of the entrepreneurial and market orientations concepts and to gauge construct validity. A principal component analysis with Varimax rotation was used.

The univariate analysis was applied in order to determine the variables that influence the profitability of beekeeping enterprises. In order to test whether the mean of the variables in the two categories of beekeeping enterprises (the category of profitable and unprofitable beekeeping enterprises) differs significantly, the Student's $t$ test was applied.

Linear regression was performed, the dependent variable being the profitability of the beekeeping enterprise and the independent variables being those variables that influence the profitability of the business according to the univariate analysis.

Hence, the following hypotheses are proposed:

Entrepreneurial orientation influences the profitability of beekeeping enterprises.

Market orientation influences the profitability of beekeeping enterprises.

The number of honeybee colonies influences the profitability of beekeeping enterprises.

The diversification of the bee products sold influences the profitability of beekeeping enterprises.

The diversification of the distribution channels influences the profitability of beekeeping enterprises. 


\section{RESULTS AND DISCUSSION}

In order to shape the entrepreneurial and market orientations in the case of French beekeeping enterprises, factor analysis was applied using the questions from the survey. Kaiser-Meyer-Olkin measure and Bartlett's test of specificity show that the variables can be used in factor analysis. One factor was created from 3 or 4 variables to avoid multicollinearity. Therefore, 3 factors emerged: innovativeness $f_{1}$, proactiveness $f_{2}$ and market orientation $f_{3}$. According to the factor analysis, the factor innovativeness consists of three items: "The enterprise has companyspecific innovative products that it currently sells", "The enterprise has marketed new product lines during the past 5 years", "The enterprise invests in the development of new products". The factor proactiveness consists also of three items: "Our main task is to pursue mostly valuable opportunities and then to acquire the suitable resources to exploit them", "We seek new markets for our bee products", "In dealing with its competitors, the enterprise is very often the first to introduce new products". The factor market orientation consists of four items: "We continually monitor customers to find new ways to improve customer satisfaction", "We poll our customers at least once per year to assess the quality of our products", "Our strategy for competitive advantage is based on our understanding of customer needs",

Tab. 1. Factor analysis for the French beekeeping enterprises

\begin{tabular}{|c|c|}
\hline Variables & Factor 1 "Innovativeness" \\
\hline $\begin{array}{l}\text { The enterprise has company-specific innovative products that it currently } \\
\text { sells. }\end{array}$ & 0.874 \\
\hline The enterprise has marketed new product lines during the past 5 years. & 0.872 \\
\hline The enterprise invests in the development of new products. & 0.858 \\
\hline Kaiser-Meyer-Olkin test: & 0.725 \\
\hline Rotation method: & Varimax \\
\hline Total variance explained: & $75.366 \%$ \\
\hline \multirow[t]{2}{*}{ Bartlet's test: } & $114.552(p=0.000)$ \\
\hline & Factor 2 "Proactiveness" \\
\hline $\begin{array}{l}\text { Our main task is to pursue mostly valuable opportunities and then to } \\
\text { acquire the suitable resources to exploit them. }\end{array}$ & 0.869 \\
\hline We seek new markets for our bee products. & 0.830 \\
\hline $\begin{array}{l}\text { In dealing with its competitors, the enterprise is very often the first to } \\
\text { introduce new products. }\end{array}$ & 0.798 \\
\hline Kaiser-Meyer-Olkin test: & 0.685 \\
\hline Rotation method: & Varimax \\
\hline Total variance explained: & $69.394 \%$ \\
\hline \multirow[t]{2}{*}{ Bartlett's test: } & $82.262(\mathrm{p}=0.000)$ \\
\hline & Factor 3 "Market orientation" \\
\hline $\begin{array}{l}\text { We continually monitor customers to find new ways to improve customer } \\
\text { satisfaction. }\end{array}$ & 0.878 \\
\hline $\begin{array}{l}\text { We poll our customers at least once per year to assess the quality of our } \\
\text { products. }\end{array}$ & 0.817 \\
\hline $\begin{array}{l}\text { Our strategy for competitive advantage is based on our understanding of } \\
\text { customer needs. }\end{array}$ & 0.774 \\
\hline Our business objectives are driven primarily by customer satisfaction. & 0.770 \\
\hline Kaiser-Meyer-Olkin test: & 0.793 \\
\hline Rotation method: & Varimax \\
\hline Total variance explained: & $65.767 \%$ \\
\hline Bartlett's test & $140.575(\mathrm{p}=0.000)$ \\
\hline
\end{tabular}


"Our business objectives are driven primarily by customer satisfaction" (Table 1).

The univariate analysis tests if the mean of the variables differs significantly in the case of enterprises that are profitable and enterprises that operate at a loss. The results of the $t$ test (Table 2) show that there is significant difference between the mean of the variable in the case of profitable enterprises and the mean of the variable in the case of unprofitable enterprises. Therefore, it can be stated that these variables influence an enterprise's profitability and will be introduced as explanatory variables in the linear regression analysis.

The results of the regression analysis are presented in Table 3. The estimates of the developed model show that innovativeness, market orientation and the number of honeybee colonies are significantly correlated with the dependant variable. The VIF coefficient indicates that there is no multicollinearity among variables. The econometric model developed reveals that the

Tab. 2. Univariate analysis for the French beekeeping enterprises

\begin{tabular}{|c|c|c|c|c|c|c|}
\hline & \multirow{2}{*}{ Profitability } & \multirow{2}{*}{$\mathrm{N}$} & \multirow{2}{*}{ Mean } & \multirow{2}{*}{$\begin{array}{l}\text { Standard } \\
\text { Deviation }\end{array}$} & \multicolumn{2}{|c|}{$\begin{array}{l}t \text {-test for equality of } \\
\text { means }\end{array}$} \\
\hline & & & & & $\mathrm{t}$ & $\begin{array}{c}\text { Sig. } \\
\text { (2-tailed) } \\
\end{array}$ \\
\hline \multirow{2}{*}{ Number of honeybee colonies } & Profitable & 72 & 120.65 & 100.900 & \multirow{2}{*}{7.308} & \multirow{2}{*}{0.000} \\
\hline & Not profitable & 28 & 30.21 & 18.126 & & \\
\hline \multirow{2}{*}{$\begin{array}{l}\text { Diversification of the bee } \\
\text { products sold }\end{array}$} & Profitable & 72 & 3.38 & 1.946 & \multirow{2}{*}{3.904} & \multirow{2}{*}{0.000} \\
\hline & Not profitable & 28 & 1.75 & 1.838 & & \\
\hline \multirow{2}{*}{$\begin{array}{l}\text { Diversification of the } \\
\text { distribution channels }\end{array}$} & Profitable & 72 & 2.40 & 1.030 & \multirow{2}{*}{3.196} & \multirow{2}{*}{0.002} \\
\hline & Not profitable & 28 & 1.68 & 0.983 & & \\
\hline \multirow{2}{*}{ Innovativeness } & Profitable & 72 & 0.309 & 0.909 & \multirow{2}{*}{6.172} & \multirow{2}{*}{0.000} \\
\hline & Not profitable & 28 & -0.796 & 0.759 & & \\
\hline \multirow{2}{*}{ Proactiveness } & Profitable & 71 & 0.245 & 0.944 & \multirow{2}{*}{4.209} & \multirow{2}{*}{0.000} \\
\hline & Not profitable & 28 & -0.622 & 0.869 & & \\
\hline \multirow{2}{*}{ Risk-taking } & Profitable & 72 & 2.38 & 1.250 & \multirow{2}{*}{2.553} & \multirow{2}{*}{0.012} \\
\hline & Not profitable & 28 & 1.68 & 1.156 & & \\
\hline \multirow{2}{*}{ Market orientation } & Profitable & 71 & 0.266 & 0.862 & \multirow{2}{*}{4.636} & \multirow{2}{*}{0.000} \\
\hline & Not profitable & 28 & -0.674 & 1.022 & & \\
\hline
\end{tabular}

Source: own calculations based on the survey

Tab. 3. Estimate of the linear regression model for the French beekeeping enterprises

Dependant variable: Profitability of the French beekeeping enterprises

\begin{tabular}{|c|c|c|c|c|c|c|c|}
\hline \multirow[t]{2}{*}{ Model } & \multicolumn{2}{|c|}{$\begin{array}{l}\text { Unstandardized } \\
\text { Coefficients }\end{array}$} & \multirow{2}{*}{$\begin{array}{c}\begin{array}{c}\text { Standardized } \\
\text { Coefficients }\end{array} \\
\text { Beta } \\
\end{array}$} & \multirow[t]{2}{*}{$\mathrm{t}$} & \multirow[t]{2}{*}{ Sig. } & \multicolumn{2}{|c|}{ Collinearity Statistics } \\
\hline & $\mathrm{B}$ & Std. Error & & & & Tolerance & VIF \\
\hline \multirow{4}{*}{$\begin{array}{c}\text { Constant } \\
\text { Innovativeness } \\
\text { No. of honeybee colonies } \\
\text { Market orientation }\end{array}$} & 1.410 & 0.055 & & 25.645 & 0.000 & & \\
\hline & -0.124 & 0.047 & -0.275 & -2.655 & 0.009 & 0.643 & 1.556 \\
\hline & -0.001 & 0.000 & -0.282 & -3.153 & 0.002 & 0.859 & 1.164 \\
\hline & -0.102 & 0.044 & -0.224 & -2.292 & 0.024 & 0.721 & 1.386 \\
\hline \multicolumn{8}{|c|}{$\begin{array}{c}\text { Adjusted R Square }=0.332 \\
\mathrm{~F}=17.059, \text { significance level } 0.000\end{array}$} \\
\hline
\end{tabular}


more a French beekeeping enterprise innovates, is market oriented and has many colonies of bees, the more it is profitable.

In order to shape the entrepreneurial and market orientations in the case of Romanian beekeeping enterprises, factor analysis was applied using the questions from the survey. Kaiser-MeyerOlkin measure and Bartlett's test of specificity show that the variables can be used in factor analysis. Therefore, 3 factors emerged: innovativeness $f_{1}$, proactiveness $f_{2}$ and market orientation $f_{3}$. The factor innovativeness consists of three items: "The enterprise has marketed new product lines during the past 5 years", "The enterprise has companyspecific innovative products that it currently sells",
"The enterprise invests in the development of new products". The factor proactiveness consists also of three items: "Our main task is to pursue mostly valuable opportunities and then to acquire the suitable resources to exploit them", "We seek new markets for our bee products", "In dealing with its competitors, the enterprise is very often the first to introduce new products". The factor market orientation consists of four items: "Our strategy for competitive advantage is based on our understanding of customer needs", "We continually monitor customers to find new ways to improve customer satisfaction", "We poll our customers at least once per year to assess the quality of our

Tab. 4. Factor analysis for the Romanian beekeeping enterprises

\begin{tabular}{|c|c|}
\hline Variables & Factor 1 "Innovativeness" \\
\hline The enterprise has marketed new product lines during the past 5 years. & 0.932 \\
\hline The enterprise has company-specific innovative products that it currently sells. & 0.929 \\
\hline The enterprise invests in the development of new products. & 0.896 \\
\hline Kaiser-Meyer-Olkin test: & 0.745 \\
\hline Rotation method: & Varimax \\
\hline Total variance explained: & $84.494 \%$ \\
\hline \multirow[t]{2}{*}{ Bartlett's test } & $321.489(\mathrm{p}=0.000)$ \\
\hline & Factor 2 "Proactiveness" \\
\hline $\begin{array}{l}\text { Our main task is to pursue mostly valuable opportunities and then to acquire } \\
\text { the suitable resources to exploit them. }\end{array}$ & 0.796 \\
\hline We seek new markets for our bee products. & 0.746 \\
\hline $\begin{array}{l}\text { In dealing with its competitors, the enterprise is very often the first to } \\
\text { introduce new products. }\end{array}$ & 0.706 \\
\hline Kaiser-Meyer-Olkin test: & 0.628 \\
\hline Rotation method: & Varimax \\
\hline Total variance explained: & 56.308 \\
\hline \multirow[t]{2}{*}{ Bartlett's test } & $52.402(p=0.000)$ \\
\hline & Factor 3 "Market orientation" \\
\hline $\begin{array}{l}\text { Our strategy for competitive advantage is based on our understanding of } \\
\text { customer needs. }\end{array}$ & 0.844 \\
\hline $\begin{array}{l}\text { We continually monitor customers to find new ways to improve customer } \\
\text { satisfaction. }\end{array}$ & 0.817 \\
\hline $\begin{array}{c}\text { We poll our customers at least once per year to assess the quality of our } \\
\text { products. }\end{array}$ & 0.809 \\
\hline Our business objectives are driven primarily by customer satisfaction. & 0.609 \\
\hline Kaiser-Meyer-Olkin test: & 0.723 \\
\hline Rotation method: & Varimax \\
\hline Total variance explained: & 60.145 \\
\hline Bartlett's test & $189.704(\mathrm{p}=0.000)$ \\
\hline
\end{tabular}


products", "Our business objectives are driven primarily by customer satisfaction" (Table 4).

The univariate analysis tests if the mean of the variables differs significantly in the case of enterprises that are profitable and enterprises that operate at a loss. The results of the $t$ test emphasise that there is significant difference between the mean of the variable in the case of profitable enterprises and the mean of the variable in the case of unprofitable enterprises. As these variables influence an enterprise's profitability, they will be introduced as explanatory variables in the linear regression analysis (Table 5).

The estimates of the developed model show that the number of honeybee colonies, innovativeness and market orientation are significantly correlated with the dependant variable (Table 6). The VIF coefficient indicates that there is no multicollinearity among factors. The econometric model developed reveals that the more a Romanian beekeeping enterprise innovates, is market oriented and has many colonies of bees, the more it is profitable.

The two econometric models developed (Table 3 and Table 6) reveal that innovativeness, market orientation and the number of honeybee colonies are the main factors that bring about the profitability of French and Romanian beekeeping enterprises. The results of the research are in line with the literature, which states that innovativeness influences firm profitability (Rauch et al., 2009; Wiklund et al., 2009). The positive effects of market orientation on business profitability are supported by previous studies as well (Baker and Sinkula, 2009; Hult and Ketchen, 2001; Slater and Narver, 1998). Earlier research has also found a positive impact of the number of honeybee colonies on the profitability of beekeeping enterprises (Masuku, 2013; Singh and Sekhon, 2014).

Following the univariate analysis, the findings of the present study partially provide support for the first hypothesis, which suggests that beekeeping enterprise profitability is influenced by the three-folded entrepreneurial orientation (innovativeness, proactiveness and risk-taking). The influence of the risk-taking dimension was not confirmed by the univariate analysis in the case of Romania. In Romania, as opposed to France, the univariate analysis shows that profitability is not influenced by the risk-taking dimension. This confirms the view of authors such as Kreiser et al. (2013), who show that there can be a negative relationship between risk-taking and performance. The idea that the three dimensions of EO may vary independently, relying on the environmental and organizational context, is consistent with the work of prior entrepreneurship scholars (Lumpkin and

Tab. 5. Univariate analysis for the Romanian beekeeping enterprises

\begin{tabular}{|c|c|c|c|c|c|c|}
\hline & \multirow{2}{*}{ Profitability } & \multirow{2}{*}{$\mathrm{N}$} & \multirow{2}{*}{ Mean } & \multirow{2}{*}{$\begin{array}{l}\text { Standard } \\
\text { Deviation }\end{array}$} & \multicolumn{2}{|c|}{$\begin{array}{l}t \text {-test for equality of } \\
\text { means } \\
\end{array}$} \\
\hline & & & & & $\mathrm{t}$ & $\begin{array}{c}\text { Sig. } \\
\text { (2-tailed) } \\
\end{array}$ \\
\hline \multirow{2}{*}{ Number of honeybee colonies } & Profitable & 141 & 125.85 & 93.617 & \multirow{2}{*}{4.116} & \multirow{2}{*}{0.000} \\
\hline & Not profitable & 19 & 74.53 & 42.105 & & \\
\hline \multirow{2}{*}{$\begin{array}{l}\text { Diversification of the products } \\
\text { sold }\end{array}$} & Profitable & 141 & 4.67 & 2.020 & \multirow{2}{*}{3.943} & \multirow{2}{*}{0.000} \\
\hline & Not profitable & 19 & 3.42 & 1.170 & & \\
\hline \multirow{2}{*}{$\begin{array}{l}\text { Diversification of the } \\
\text { distribution channels }\end{array}$} & Profitable & 141 & 2.43 & 1.104 & \multirow{2}{*}{3.192} & \multirow{2}{*}{0.003} \\
\hline & Not profitable & 19 & 1.95 & 0.524 & & \\
\hline \multirow{2}{*}{ Innovativeness } & Profitable & 141 & 0.120 & 0.940 & \multirow{2}{*}{4.373} & \multirow{2}{*}{0.000} \\
\hline & Not profitable & 19 & -0.892 & 1.000 & & \\
\hline \multirow{2}{*}{ Proactiveness } & Profitable & 141 & 0.122 & 0.893 & \multirow{2}{*}{3.421} & \multirow{2}{*}{0.003} \\
\hline & Not profitable & 19 & -0.910 & 1.275 & & \\
\hline \multirow{2}{*}{ Market orientation } & Profitable & 141 & 0.089 & 0.958 & \multirow{2}{*}{3.165} & \multirow{2}{*}{0.002} \\
\hline & Not profitable & 19 & -0.663 & 1.079 & & \\
\hline
\end{tabular}


Dess, 1996; Hughes and Morgan, 2007). Kraus et al. (2012) state that, in turbulent environments, innovative SMEs should take action to avoid projects that are too risky. Market orientation was found to impact on profitability in both countries, backing up the second hypothesis. Aguiar and Sejdaras (2008) found that the lack of knowledge regarding consumers' requirements discourages many beekeepers, therefore they should adjust their business strategies towards a more marketoriented approach.

Concerning the third hypothesis, the univariate analysis and the linear regression confirm that the number of honeybee colonies influences profitability. This is consistent with the findings of Singh and Sekhon (2014), who state that large beekeeping enterprises are getting more returns in comparison to small and medium ones. The results are also supported by Masuku (2013), who recommends an increase in the colony size for improving honey production and profit.

The fourth hypothesis is also confirmed by the univariate analysis, the diversification of the bee products sold being an important influencing factor on the profitability of beekeeping enterprises. Beekeeping enterprises have the possibility to sell a variety of products, not only honey, adopting the diversification strategy and ensuring economic survival. Roman et al. (2013) indicate that the main factors that trigger the profitability of the beekeeping activity are the production and selling of apiary products. Marinković and Nedić (2010) recommend apicultural enterprises to re-direct their business orientation to other bee products besides honey (such as pollen). The other products, apart from honey, may be even more profitable than honey if consumers know the product and its use. Therefore, apicultural enterprises should make an effort to increase consumers' awareness of the nutritional and health benefits of propolis, pollen and royal jelly.

Finally, the results support the fifth hypothesis, which suggests that the diversification of the distribution channels influences enterprise profitability both in France and Romania. The results are in line with the findings of Mogni et al. (2009), who underline the importance of efficient honey distribution channels, as bee products should be available for all consumers.

\section{CONCLUSION}

The main purpose of the research was to investigate the influence of the entrepreneurial and market orientations, the number of honeybee colonies, the diversification of bee products sold and of the distribution channels upon the profitability of apicultural enterprises. The research sought to determine the strategies which beekeepers need to implement in order to identify new opportunities and be competitive.

The findings indicate similarities between the two countries under study as the estimated econometric model reveals that innovativeness, market orientation and the number of honeybee colonies positively affect profitability of beekeeping enterprises both in France and Romania. The three factors identified sustain an enterprise's competitive advantage due to the fact that innovative and market oriented beekeeping enterprises position themselves in anticipation of

Tab. 6. Estimate of the linear regression model for the Romanian beekeeping enterprises

Dependant variable: Profitability of the Romanian beekeeping enterprises

\begin{tabular}{|c|c|c|c|c|c|c|c|}
\hline \multirow[t]{2}{*}{ Model } & \multicolumn{2}{|c|}{$\begin{array}{c}\text { Unstandardized } \\
\text { Coefficients }\end{array}$} & \multirow{2}{*}{$\begin{array}{c}\begin{array}{c}\text { Standardized } \\
\text { Coefficients }\end{array} \\
\text { Beta }\end{array}$} & \multirow[t]{2}{*}{$\mathrm{t}$} & \multirow[t]{2}{*}{ Sig. } & \multicolumn{2}{|c|}{$\begin{array}{c}\text { Collinearity } \\
\text { Statistics }\end{array}$} \\
\hline & B & Std. Error & & & & Tolerance & VIF \\
\hline \multirow{4}{*}{$\begin{array}{c}\text { Constant } \\
\text { No. of honeybee colonies } \\
\text { Innovativeness } \\
\text { Market orientation }\end{array}$} & 1.180 & 0.041 & & 28.938 & 0.000 & & \\
\hline & -0.001 & 0.000 & -0.143 & -1.857 & 0.065 & 0.917 & 1.091 \\
\hline & -0.078 & 0.026 & -0.241 & -3.006 & 0.003 & 0.848 & 1.179 \\
\hline & -0.061 & 0.025 & -0.188 & -2.407 & 0.017 & 0.892 & 1.121 \\
\hline The $\mathrm{d}$ & dont & $\begin{array}{r}\text { R Squ } \\
.271 \text {, sign } \\
\text { able was cc }\end{array}$ & $\begin{array}{l}\text { are }=0.167 \\
\text { ficance level } 0 . \\
\text { ded } 1 \text { - profital }\end{array}$ & $\begin{array}{l}00 \\
e, 2-\text { not }\end{array}$ & fitabl & & \\
\hline
\end{tabular}


changes in the market, create new opportunities, innovate and engage in entrepreneurial actions, strategies that are considered the source of competitive advantage (Kuratko, 2009). Identifying latent customer needs represents a source of competitive advantage, as a firm can create a competitive advantage by anticipating changes in future demand (Lumpkin and Dess, 1996). According to Narver et al. (2004), for any business to create and to maintain sustainable competitive advantage, it must increase its proactive market orientation continually.

The findings also suggest that proactiveness and the diversification of the products sold and of the distribution channels represent strategies that influence the profitability of beekeeping enterprises in both countries. In France, risktaking influences profitability, as opposed to Romania, currently a developing country, in which case risk-taking does not influence profitability.

The study contains limitations that provide opportunities for future research. One possible limitation lies in the sample, as the electronic data collection did not yield a very high response rate. Strategies to encourage a higher response rate would be necessary for future studies, targeting other European Union countries. Another limitation of the study is that it does not include all the items of the existing measures for entrepreneurial orientation and market orientation as presented in the scholarly literature (Covin and Slevin, 1989; Deshpande and Farley, 1998). These adaptations were necessary in order to tailor the survey to beekeeping enterprises.

Despite its limitations, the present study makes a number of contributions to the literature regarding the understanding of the role played by entrepreneurial and market orientations upon beekeeping enterprises. Further studies should analyse the profitability of innovative and market oriented beekeeping enterprises and compare their profitability with firms which do not implement these business strategies, over a longer period of time.

The research provides guidelines for beekeeping enterprise owner-managers regarding the role of entrepreneurial and market orientations upon business profitability. The owners of beekeeping enterprises can use the current findings as a reference point in the formulation of management strategies in order to gain a competitive advantage and develop their entrepreneurial skills. They should understand market changes and continuously adapt to current and latent customer needs, offering them innovative products.

Acknowledgments. This paper was published under the frame of European Social Fund, Human Resources Development Operational Programme 2007-2013, project no. POSDRU/159/1.5/S/132765.

\section{REFERENCES}

1. Aguiar LK, Sejdaras A (2008). Recent developments in the apiculture sector in Albania: the insertion of beekeepers into the EU honey supply chain. Acta Horticulturae 794:25 -31 .

2. Alvarez SA (2007). Entrepreneurial rents and the theory of the firm. Journal of Business Venturing 22(3):427-442.

3. Atuahene-Gima K, Ko A (2001). An empirical investigation of the effect of market orientation and entrepreneurship orientation alignment on product innovation. Organization Science 12(1):54-74.

4. Baker WE, Sinkula JM (2009). The complementary effects of market orientation and entrepreneurial orientation on profitability in small business. Journal of Small Business Management 47(4):443-464.

5. Bodescu D, Stefan G, Paveliuc CO (2009). The comparative profitability of Romanian apiarian exploitations on size categories. Bulletin UASVM Horticulture 66(2):514.

6. Chauzat MP, Cauquil L, Roy L, Franco S, Hendrikx P, Ribière-Chabert M (2013). Demographics of the European Apicultural Industry. PloS ONE 8(11): e79018.

7. Covin JG, Slevin DP (1989). Strategic management of small firms in hostile and benign environments. Strategic Management Journal 10(1):75-98.

8. Deshpande R, Farley J (1998). Measuring market orientation: generalization and synthesis. Journal of Market Focused Management 2(3):213-232.

9. Hughes M, Morgan RE (2007). Deconstructing the relationship between entrepreneurial orientation and business performance at the embryonic stage of firm growth. Industrial Marketing Management 36(5):651661.

10. Hult GT, Ketchen DJ (2001). Does market orientation matter?: A test of the relationship between positional advantage and performance. Strategic Management Journal 22(9):899-906.

11. Ireland RD, Hitt MA (1999). Achieving and maintaining strategic competitiveness in the $21^{\text {st }}$ century: The role of strategic leadership. Academy of Management Executive 13(1):43-57.

12. Ja'afar-Furo MR (2007). Appraising the perception of farming communities towards adoption of apiculture as a viable source of income in Adamawa State, Nigeria. Apiacta 42:1-15. 
13. Jaworski BJ, Kohli AK (1993). Market orientation: antecedents and consequences. Journal of Marketing 57:53-70.

14. Kalule SW, Ssebbale E (2014). Financial performance and technical efficiency differentials for apicultural technologies in Nakaseke District, Uganda. The Journal of Developing Areas 48(1):387-404.

15. Kraus S, Rigtering JPC, Hughes M, Hosman V (2012). Entrepreneurial orientation and the business performance of SMEs: a quantitative study from the Netherlands. Review of Managerial Science 6(2):161-182.

16. Kreiser PM, Marino LD, Kuratko DF, Weaver MK (2013). Disaggregating entrepreneurial orientation: The nonlinear impact of innovativeness, proactiveness and risktaking on SME performance. Small Business Economics 40(2):273-291.

17. Kreiser PM, Marino LD, Weaver KM (2002). Assessing the psychometricproperties of the entrepreneurialorientation scale: a multi-country analysis. Entrepreneurship Theory and Practice 26(4):71-94.

18. Kuratko DF (2009). The entrepreneurial imperative of the $21^{\text {st }}$ century. Business Horizons 52 (5):421-428.

19. Lumpkin GT, Dess GG (1996). Clarifying the entrepreneurial orientation construct and linking it to performance. Academy of Management Review 21(1):135-172.

20. Makri P, Paschalidis V, Papanagiotou P, Papanagiotou E (2012). An economic analysis of Greek beekeeping. In: Sustainable agriculture and food production: adaptations to a changing social, economic and institutional environment, $11^{\text {th }}$ biannual conference of the Hellenic Association of Agricultural Economists, Thessaloniki, Greece, 26-27 November 2010, 59-72.

21. Marinković S, Nedić N (2010). Analysis of production and competitiveness on small beekeeping farms in selected districts of Serbia. Applied Studies in Agribusiness and Commerce 4:1-5.

22. Masuku MB (2013). Socioeconomic analysis of beekeeping in Swaziland: A case study of the Manzini Region, Swaziland. Journal of Development and Agricultural Economics 5(6):236-241.

23. Miller D (1983).The correlates of entrepreneurship in three types of firms. Management Science 29: 770-791.

24. Miller KD, Leiblein MJ (1996). Corporate risk-return relations: Returns variability versus downside risk. Academy of Management Journal 39(1):91-122.

25. Mogni F, Tresoldi C, Senesi S, Palau H, Vilella F (2009). Sustainable development in food and agribusiness: application of the theoretical model to the Argentine beekeeping sector. VII International PENSA Conference. Nov, 26-28th, Sao Paulo, Brazil,1-16.

26. Morris MH, Kuratko DF, Covin JG (2011). Corporate Entrepreneurship \& Innovation ( $3^{\text {rd }}$ ed.). Mason: SouthWestern/Cengage Publishers; ISBN-13: 9781111526917.

27. Narver JC, Slater SF (1990). The effect of a market orientation on business profitability. Journal of Marketing 54:20-35

28. Narver JC, Slater SF, MacLachlan DL (2004). Responsive and proactive market orientation and new-product success. Journal of Product Innovation Management 21(5):334-347.

29. Pocol CB, Popa AA (2012). Types of beekeeping practiced in the North-West region of Romania - advantages and disadvantages. Bulletin UASVM Horticulture 69(2):239243.

30. Popescu A (2012). Research on beekeepers income estimation based on honey production. Bulletin UASVM Animal Science and Biotechnologies 69(1-2):185-191.

31. Rauch A, Wiklund J, Lumpkin GT, Frese M (2009). Entrepreneurial orientation and business performance: an assessment of past research and suggestions for the future. Entrepreneurship Theory and Practice 33(3):761787.

32. Roman A, Popiela-Pleban E, Kozak M (2013). Factors influencing consumer behavior relating to the purchasing of honey part 1 . The buying process and the level of consumption. Journal of Apicultural Science 57(2):159172.

33. Singh B, Sekhon MK (2014). Economics of honey production in Punjab. Journal of Agricultural Development and Policy 24(1):85-94.

34. Slater SF, Narver JC (1998). The positive effect of a market orientation on business profitability: a balanced replication. Journal of Business Research 48:69-73.

35. Venkatraman N (1989). Strategic orientation of business enterprises: the construct, dimensionality and measurement. Management Science 35(8):941-962.

36. Wiklund J (1999). The sustainability of the entrepreneurial orientation-performance relationship. Entrepreneurship Theory and Practice 24(1):37-48.

37. Wiklund J, Patzelt H, Shepherd DA (2009). Building an integrative model of small business growth. Small Business Economics 32:351-374.

38. Wiklund J, Shepherd D (2005). Entrepreneurial orientation and small business performance: a configuration approach. Journal of Business Venturing 20 (1):71-91. 